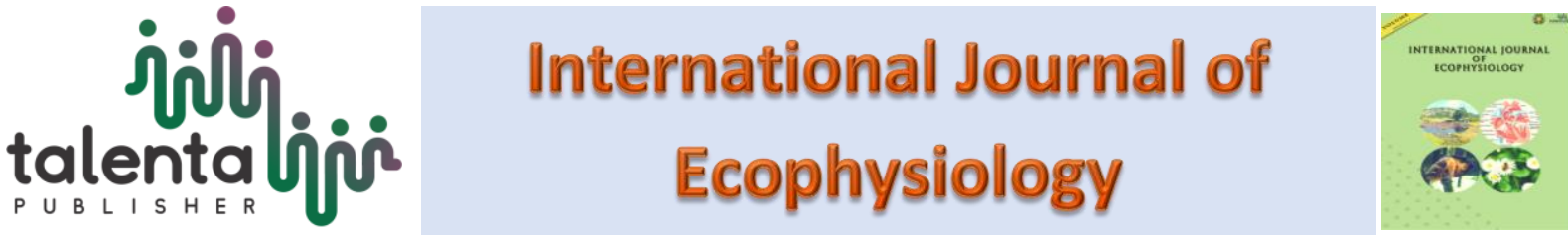

\section{Histology of Spleen after Induction Nanoherbal Rhodomyrtus tomentosa}

\author{
Syafruddin Ilyas ${ }^{1}$, Putri Cahaya Situmorang ${ }^{1}$, Salomo Hutahaean ${ }^{1}$ \\ Rosidah $^{2}$ \\ ${ }^{I}$ Department of Biology, Faculty of Mathematics and Natural Sciences, Universitas Sumatera Utara, \\ Medan, Indonesia, 20155 \\ ${ }^{2}$ Faculty of Pharmacy, Universitas Sumatera Utara, Jalan Dr.Mansyur Medan, Indonesia, 20155
}

\begin{abstract}
The study aim to know to effect of Nanoherbal Rhodomyrtus tomentosa (Haramonting) on spleen histology of Mus musculus. Haramonting in Indonesia as a new source of health-promoting compounds such as dietary fibers, essential fatty acids, and phenolic compounds because there are 19 phenolic compounds including stilbenes and ellagitannins as major components, followed by anthocyanins, flavonols, and gallic acid. Haramonting is made on a nanoscale using High Energy Milling (HEM). This research use the Completely Randomized Design (CRD) at dosage of $(100 ; 141,42 ; 200 ; 282,82$; $400) \mathrm{mg} / 20 \mathrm{~g}$ body weight. The spleen were made into preparations by using the paraffin method and Hematoxylin Erlich-Eosin staining (HE). There were a significant difference $(\mathrm{P}<0,05)$ between control group and treatment groups on form of spleen cells although no significant in spleen weight.
\end{abstract}

Keyword: Nanoherbal, Rhodomyrtus tomentosa, spleens, Alveolus, Histology

Received 17 November 2019 | Revised 24 December2019| Accepted 28 January2020

\section{Introduction}

Nanoherbal is the herb that uses nanoscale technology (wave power) and use quality herbal raw materials. The use of herbal remedies has been practiced for thousands of years and a part of several countries such as Indonesia, China and India. Nanotechnology commonly refers to structures that are up to several $100 \mathrm{~nm}$ in size which can be increased up to $1000 \mathrm{~nm}$. Nanotechnology and nano science studies have develops briskly during the past years in a large range of product results. It gives opportunities for the development of materials, including those for medical applications, where conventional techniques may reach their limits [1]. Herbal medicines have less adverse effects as compared with modern medicines due to poor solubility, poor permeability, low bioavailability, instability in biological milieu and extensive first pass

*Corresponding author at: Jl. Bioteknologi No. 1 Kampus Univ. Sumatera Utara, Padang Bulan, Medan, Indonesia 
metabolism by developing new formulation as nano herbal medicines like nanoparticles, dendrimers, Nano crystals, Quantum dots, Nanosperes, Nanocapsules, herbal market get good feedback [2]. One study using nano herbal is Nano curcumin. In this study Nano-curcumin significantly inhibited the growth of MCF-7 breast cancer cell line and resulted in synergism cytotoxicity effects [3].

Rhodomyrtus tomentosa in Indonesia, especially in North Sumatra, is called haramonting Rhodomyrtus tomentosa (Aiton) Hassk. (Family Myrtaceae) is an ornamental, evergreen shrub grows up to four meters tall. This plant species is native to southern and southeastern Asia [4]. The discoveries reported in the study highlight the potential of $R$. tomentosa as a new source of health-promoting compounds such as dietary fibers, essential fatty acids, and phenolic compounds. A total of 19 phenolic compounds were tentatively characterized, including stilbenes and ellagitannins as major components, followed by anthocyanins, flavonols, and gallic acid. Piceatannol, a promising health-promoting stilbene component [5]. Studies on haramonting mainly focused on the bioactive compounds from leaves and aerial parts because of their antibacterial, DNA damage prevention, and antioxidant activities [6]. However, using Nanoherbal of haramonting has not been done on spleen. So, Nanoherbal haramonting as a new alternative in the treatment, expecially problem in spleen.

\section{Materials and Methods}

The material used is male mice (Mus musculus L) strain DDW, Haramonting leaves (R.tomentosa) obtained from plantation residents in Tapanuli North Sumatera, Feed the mice no. PB 551, staining Hematoxylin and Eosin. This research use the Completely Randomized Design (CRD) using 30 male mice with an average weight of 20-25g age 12-18 weeks. Male mice are kept in Animal Cages Biological Laboratory, Faculty Mathematics and Natural Science, Universitas Sumatera Utara. Experimental animal handling is done ethically (Ethical Clearance). The procedure is same with tresearch before.

\section{Result and Discussion}

Haramonting administration was not significantly different in weight of spleen $(\mathrm{P}>0,05)$ and haramonting with multilevel doses can cause significant damage to the spleen with $\mathrm{P}<0.05$ but in T1 with T2, T3, T4, and T5, T2 with T3, T4, T5 and T3 with T4, T5 were not significant of damage $(\mathrm{P}>0.05)$. Examination of necrosis is 0 if $95 \%$ of spleen cells are normal (cell nucleus is clear, cytoplasm is full) and lymphocyte cells density reaches $95 \%$, given a score of 1 , if necrosis of lymphocyte cell is around 25\%, given a score of 2 if necrosis of ymphocyte cells less than or equal to $50 \%$, given a score of 3 if necrosis of lymphocyte cells is more than $50 \%$. The increase begin at the lowest dose (T1) to T5 with almost the same level of damage. The 
highest increase in cell damage was in $\mathrm{T} 3$ and $\mathrm{T} 5$ and the lowest was in the control (CMC 0.5\%) (Figure 1).

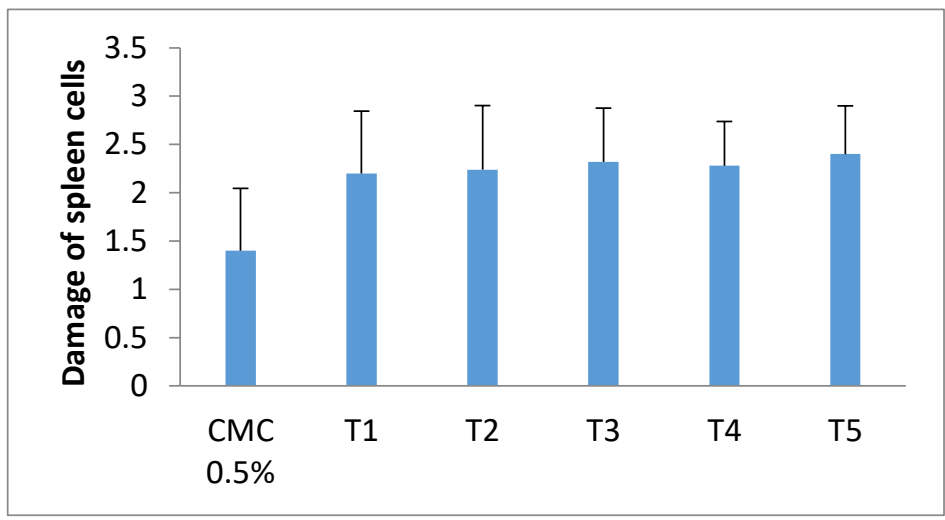

Figure 1. Comparison of Spleen cell damage $( \pm S D)$.
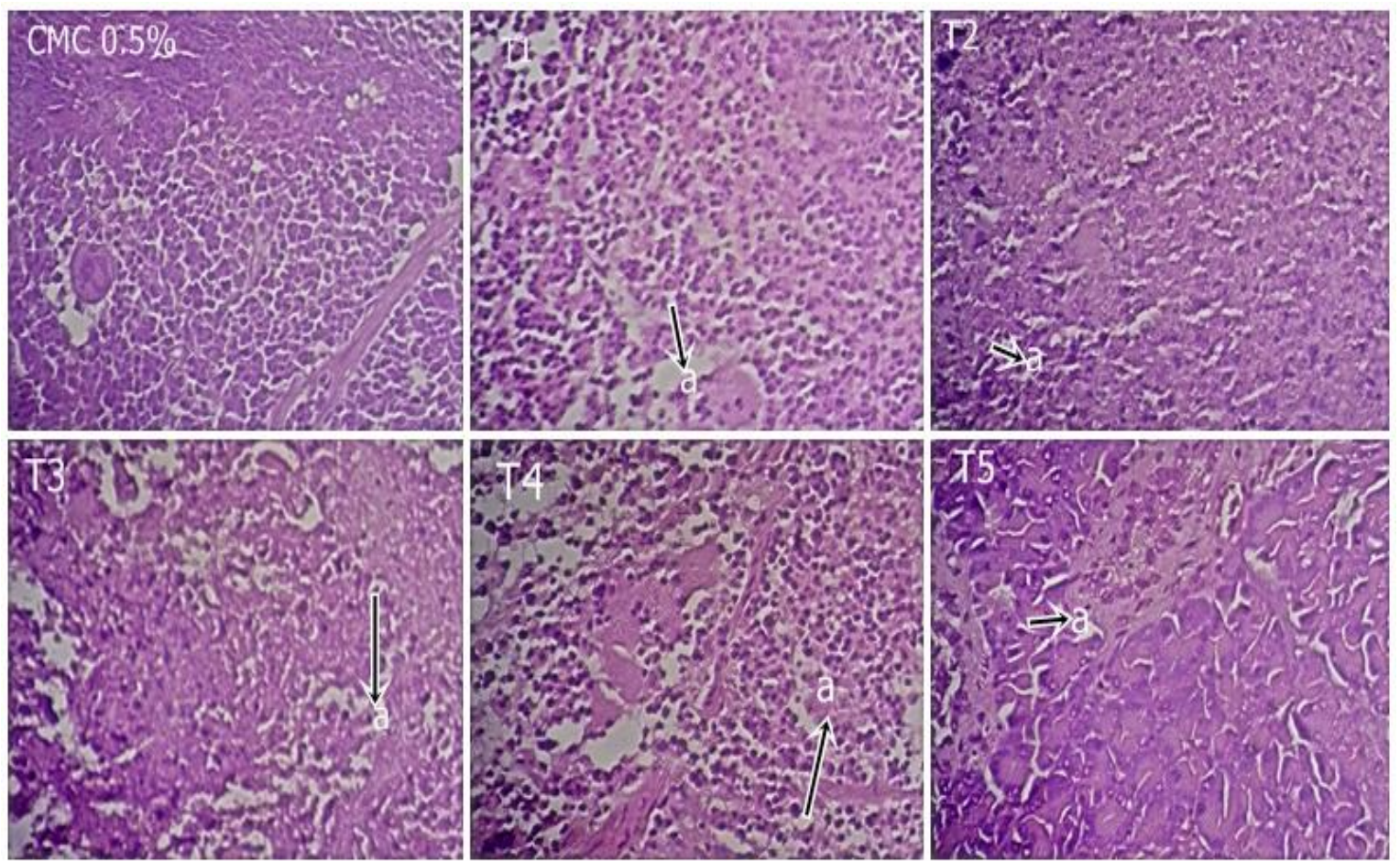

Figure 2. Histology of spleen after giving haramonting. A. Necrosis (400x).

Immune system can be a primary target for toxic effects of environmental pollutants and often takes place changes before other toxicity [7]. Immune status in patients with various diseases is widely evaluated by lymphocyte analyses in blood. Damage of lymphocyte cells can disrupt the Immune system in spleen. Infection of substances that enter the blood can lead to sepsis up to necrosis. Giving Nano- $R$. tomentosa (Haramonting) with excessive doses can cause cell damage and interfere with the immune system in the spleen. In addition to Haramonting [8],[9], necrosis in the spleen can also be caused by several things such as lack of blood supply, toxin, no nerve innervation, temperature, radioactive light and mechanical trauma [10].

Immune system can be a primary target for toxic effects of environmental pollutants and often takes place changes before other toxicity [7]. Immune status in patients with various diseases 
is widely evaluated by lymphocyte analyses in blood. Damage of lymphocyte cells can disrupt the Immune system in spleen. Infection of substances that enter the blood can lead to sepsis up to necrosis. Giving Nano-R.tomentosa (Haramonting) [11] with excessive doses can cause cell damage and interfere with the immune system in the spleen. In addition to Haramonting, necrosis in the spleen can also be caused by several things such as lack of blood supply, toxin, no nerve innervation, temperature, radioactive light and mechanical trauma [10].

\section{Conclusion}

Effect of nanoherbal haramonting in spleen was significantly different from each treatment $(\mathrm{P}<0.05)$ and giving haramonting with excessive doses can cause cell damage and interfere with the immune system in the spleen

\section{Aknowledgement}

We are grateful to Directorate of research and community service, Directorate general of research and development, Ministry of research, Technology, and Higher Education in accordance with research and community service funding agreement on DRPM funds years 2019 (PDD- Number:11/E1/KP.PTNBH/2019).

\section{REFERENCES}

[1] Ratnam, D.,V., Ankola, D.,D., Bhardwaj, V., Sahana, D.,K., Kumar, M.,N., 2006, Role of antioxidants in prophylaxis and therapy: a pharmaceutical prospective, $\mathrm{J}$ control release. International journal of molecular sciences. 113:189- 207.

[2] Rinku, Y., Pati, Shubhangi, A., Patil, Niranjan, D., Chivate, Yogesh, N., Patil, 2018, Herbal Drug Nanoparticles: Advancements in Herbal Treatment. Research J. Pharm. and Tech. 11(1)

[3] ZiaSarabi P, Hesari A, Bagheri M, Baazm M, Ghasemi F. Evaluation of Cytotoxicity Effects of Combination Nano-Curcumin and Berberine in Breast Cancer Cell Line. IJT. 2018; 12 (4) :47-50.

[4] Winotai, A., Tony, W., and Jhon, A.G., Herbivores in Thailand on Rhodomyrtus tomentosa (Myrtaceae), an invasive weed in Florida. Flor Ento 2005. 88 (1):104- 105.

[5] Lai, T.N., Herent, M.F., Quetin-Leclercq, J., Nguyen, T.B., Rogez, H., Larondelle, Y., et al. Piceatannol, a potent bioactive stilbene, as major phenolic component in Rhodomyrtus tomentosa. Food Chem 2013,138(2-3):1421-30.

[6] Limsuwan, S., Trip, E.N., Kouwen., T.R., Piersma, S., Hiranrat, A., Mahabusarakam, W., et al. Rhodomyrtone: A new candidate as natural antibacterial drug from Rhodomyrtus tomentosa. Phytomedicine, 2009,16(6): 645-651.

[7] Wang F, Liu F, Liu H, Chen W, Si X, Ma X. Effects of immunological and hematological parameter in mice exposed to mixture of volatile organic compounds. Inhal Toxicol 2016; 28, 164-169.

[8] Ilyas S., R S Tanjung, D Thahira and J Wulandari. Effectiveness of Administration Haramounting Leaf (Rhodomyrtus Tomentosa) as Antioxidant in Preventing the Damage Pancreas Mice (Mus Musculus L.) after Exposure Of Electric Cigarette Smoke. Journal of Physics: Conference Series. Journal Of Physics: Conference Series, Volume 1116, Issue 5. 2018.

[9] Ilyas S., Salomo Hutahaean, F Murdela. Antioxidant Activity of Haramounting Leaf Ethanol Extract (Rhodomytrus tomentosa) In Preventing Heart Damage of Mice (Mus 
musculus L.) After Exposure To Electronic Cigarette. IOP Conference Series Earth And Environmental Science 305:012080. 2019

[10] Berata IK, Winaya IBO, Adi AAAM, Adnyana IBW. Patologi Veteriner Umum. Denpasar: Swasta Nulus.2011

[11] Situmorang PC and Ilyas S. 2018. Description of Testes Histology of Mus musculus after giving nano hebal Rhodomyrtus tomentosa (Haramonting). Asian J Pharm Clin Res 11 issue 11 . 